\title{
Identification of a methylation hotspot in the death receptor Fas/CD95 in bladder cancer
}

\author{
C.J.WATSON ${ }^{*}$, H. O'KANE ${ }^{1 *}$, P. MAXWELL ${ }^{2}$, O. SHARAF ${ }^{3}$, I. PETAK ${ }^{4}$, P.L. HYLAND ${ }^{1}$, \\ D. O'ROUKE ${ }^{5}$, J. McKNIGHT ${ }^{1}$, P. CANNING ${ }^{6}$ and K. WILLIAMSON ${ }^{1}$ \\ ${ }^{1}$ Centre for Cancer Research and Cell Biology, Queens University Belfast; ${ }^{2}$ Tissue Pathology, Belfast Health \\ and Social Care Trust, Belfast, Northern Ireland, UK; ${ }^{3}$ St. Vincent's University Hospital and Conway Institute \\ University College Dublin, Dublin, Ireland; ${ }^{4}$ Department of Medical Chemistry, Molecular Biology and \\ Pathobiochemistry, Semmelweis University, Budapest, Hungary; ${ }^{5}$ Department of Pathology, Belfast City \\ Hospital; ${ }^{6}$ Centre for Infection and Immunity, Queen's University Belfast, Belfast, Northern Ireland, UK
}

Received August 31, 2011; Accepted October 7, 2011

DOI: 10.3892/ijo.2011.1250

\begin{abstract}
We characterized Fas immunoreactivity, functionality and its role in the response to mitomycin-C (MMC) chemotherapy in vitro in cell lines and in vivo in bladder washings from 23 transitional cell carcinoma of the bladder (TCCB) patients, harvested prior to and during MMC intravesical treatment. Having established the importance of functional Fas, we investigated the methylation and exon 9 mutation as mechanisms of Fas silencing in TCCB. For the first time, we report p53 up-regulation in 9/14 and Fas up-regulation in 7/9 TCCB patients during intravesical MMC treatment. Fas immunoreactivity was strong in the TCCB cell line T24 and in 17/20 (85\%) tumor samples from patients with advanced TCCB. T24 and HT1376 cells were resistant to MMC and recombinant Fas ligand, whilst RT4 cells were responsive to Fas ligand and MMC. Using RT4 cells as a model, siRNA targeting p53 significantly reduced MMC-induced p53 and Fas up-regulation and stable DN-FADD transfection decreased MMC-induced apoptosis, suggesting that functional Fas enhances chemotherapy responses in a p53-dependent manner. In HT1376 cells, 5-aza-2-deoxycytidine (12 $\mu \mathrm{M})$ induced Fas immunoreactivity and reversed methylation at CpG site -548 within the Fas promoter. This site was methylated in 13/24 (54\%) TCCB patient samples assessed using Methylation-Specific Polymerase Chain Reaction. There was no methylation at either the p53 enhancer region within the first intron or at the SP-1 binding region in the promoter and
\end{abstract}

Correspondence to: Dr Kate Williamson, Centre for Cancer Research and Cell Biology, Queens University Belfast, 97 Lisburn Road, Belfast, County Antrim BT9 7BL, Northern Ireland, UK

E-mail: k.williamson@qub.ac.uk

${ }^{*}$ Contributed equally

Key words: methylation, Fas, bladder cancer, p53, mitomycin-C no mutation within exon 9 in tumor DNA extracted from 38 patients. Methylation at $\mathrm{CpG}$ site -548 is a potential target for demethylating drugs.

\section{Introduction}

Activation of the death receptor Fas pathway can occur through binding with Fas ligand (Fas-L), which is expressed on cytotoxic immune cells, namely natural killer cells and activated $\mathrm{T}$ lymphocytes $(1,2)$. This pathway facilitates the elimination of unwanted cells and therefore provides an important means of tumor immune surveillance. Loss of Fas protein has been implicated in tumorigenesis (3-5); reduced Fas expression has been associated with higher stage and grade bladder tumors $(6,7)$ and introduction of Fas cDNA has been considered as a therapeutic option (8).

Ablation of Fas protein expression could be attributable to mutations or epigenetic silencing $(9,10)$. During carcinogenesis, cancer cells acquire alterations in methylation patterns (11). DNA methylation occurs through the enzymatic addition of a methyl group to the carbon five prime position of a cytosine pyrimidine ring of DNA and is almost exclusively restricted to $\mathrm{CpG}$ dinucleotides. Hypermethylation increases with aging, is associated with gene silencing and constitutes a stable mark that is maintained through continuous rounds of cell division. Generally in cancer, there is hypomethylation in intergenic regions of the genome and hypermethylation within promoter regions, particularly of tumor suppressor genes and this leads to epigenetic silencing (12). For example, $C D K N 2 A, C D H I$ (E-cadherin) and $S N C G$ are silenced through hypermethylation in urothelial cancers (13-16). Some studies have recently appraised the methylation status of panels of genes in TCCB $(11,17)$. The promoter region of Fas is GC rich and contains a relatively high number of $\mathrm{CpG}$ dinucleotides, as does the p53 responsive element within its first intron. These areas are potential targets for DNA methylation (18). DNA methylation of the Fas gene has been demonstrated in colorectal cancer (19). However, although Lee et al have reported missense mutations within exon 9 , which may affect the critical death 
domain (20), to date no study has examined the importance of hypermethylation of the Fas gene in transitional cell carcinoma of the bladder (TCCB).

This study highlights the importance of Fas functionality in the response to mitomycin-c (MMC) induced apoptosis and then tests the hypothesis that methylation within the Fas promoter silences Fas expression in TCCB cells. We identified CpG methylation site at position -548 of the Fas promoter, which was present in 13/24 (54\%) of TCCB tumors investigated.

\section{Materials and methods}

Patients and tissues. Two studies were approved by the Research Ethics Committees, Queen's University Belfast (334/00) and ORECNI (392/02) and hospital review boards. Written consent was obtained from each patient. Patients, naïve to any treatment, were recruited prior to transurethral resection of bladder tumor (TURBT) from two Belfast hospitals between January 2001 and April 2005 (Fig. 1). All patient notes were reviewed to determine which tumors recurred or progressed.

Fifteen patients were recruited to Study 1 to study p53 up-regulation post-MMC treatment in bladder washings. Fifty patients were recruited to Study 2; 34 for analyses of tumor samples only and 16 for analyses of both dynamic up-regulation of Fas in bladder washings and immunohistochemical and molecular analyses of their corresponding tumor samples.

Assessment of the levels of p53 and Fas protein in vivo in tumor cells after MMC treatment. The 15 patients recruited to Study 1 were admitted on three occasions, one week apart, and received intravesical $40 \mathrm{mg} / 40 \mathrm{ml}$ MMC (Kyowa Hakko, Ltd., UK) for $1 \mathrm{~h}$, prior to transurethral resection of bladder tumor (TURBT), as described by Maffezzini et al (21). On each admission, patients had bladder washings prior to and at $1.5,4.0$ and $6.0 \mathrm{~h}$ post-MMC. To study the dynamics of Fas expression, 16 patients recruited to Study 2 received MMC prior to TURBT in a manner similar to that described for $\mathrm{p} 53$ in Study 1. Samples from the first four patients were used to optimise protocols for Fas immunostaining. The assessment timings were prior to and 2.0, 4.0, 6.0 and 24.0 h after MMC treatment to accommodate the immediate immunostaining which was required for Fas detection on unfixed cells.

In both Study 1 and 2, immunocytochemistry was performed on tumor cells retrieved from bladder washings prior to and after MMC chemotherapy. Unfixed (Fas) or methanol fixed (p53) cells were incubated for $1 \mathrm{~h}$ at RT with $1.5 \mu \mathrm{g} /$ $\mathrm{ml}$ Fas conjugated to R-phycoerythrin (RPE) (DX2-RPE) or $8.0 \mu \mathrm{g} / \mathrm{ml}$ anti-p53 (DO7), respectively. Matching IgG antibodies at equivalent concentrations were run as controls. p53 antibody binding was visualized using RPE (Dako). Nuclear p53 and cytoplasmic Fas were confirmed using a confocal Leica SP2 microscope prior to analysis on a Coulter Epics Elite ESP flow cytometer. Seven thousand five hundred events, gated to exclude debris and doublets, were analysed for each sample. Isotype controls were analysed immediately prior to their corresponding test samples which were both run at the same voltage. Overlay histograms representing Fas or p53 protein expression levels at each time-point were appraised by two independent observers. Patients were classified as

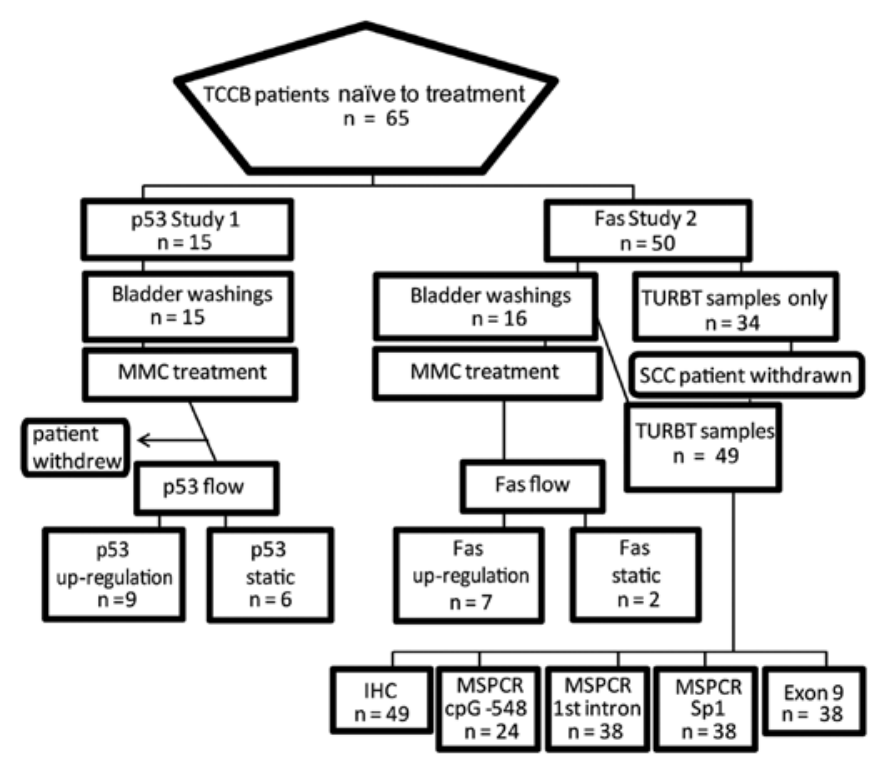

Figure 1. Patients and treatments. Sixty-five patients with bladder cancer were recruited to two studies. One patient was found to have squamous cell carcinoma (SCC) of the bladder and was withdrawn from the study. Fas and p53 immunoreactivity were appraised in 49 transurethral resection of bladder tumor (TURBT) samples using immunohistochemistry (IHC). Following DNA extraction 24 TURBT samples were assessed for methylation at $\mathrm{CpG}$ (-548) within the Fas promoter using methylation specific PCR (MSPCR); 38 were assessed for methylation at the p53 enhancer region of intron 1 and 38 for methylation in the area adjacent to an SP-1 transcription factor binding site. Thirty-eight TURBT samples were screened for mutations in exon 9 of Fas.

dynamic up-regulators if the p53 or Fas levels increased above the pre-treatment levels at any post-treatment time-point.

Assessment of tumor cells retrieved from sequential bladder washings. An aliquot of cells retrieved from each bladder washing was fixed immediately in cytospin collection fluid (Shandon, Browne, Ltd., Mallusk, Northern Ireland) and Papanicolaou stained using the Shandon Varistain 24.3 prior to assessment by a pathologist.

Fas and p53 immunohistochemistry on tumor samples. Tissue sections $(3 \mu \mathrm{m})$ cut from TURBT samples from 49/50 patients recruited to Study 2 were treated with $0.01 \mathrm{M}$ citrate buffer at $\mathrm{pH} 6.0$ for $22 \mathrm{~min}$ in a microwave oven at $750 \mathrm{~W}$ before incubation with $3 \mu \mathrm{g} / \mathrm{ml}$ anti-Fas, $5 \mu \mathrm{g} / \mathrm{ml}$ anti-p53 or isotype controls. One patient with squamous cell carcinoma of the bladder was excluded. Immunoreactivity was detected using EnVision (Dako). Two independent observers classified tumors as Fas positive when $>10 \%$ of tumor cells had cytoplasmic or membranous positivity and p53 positive when $>10 \%$ of tumor cells had nuclear positivity.

Cell culture and in vitro treatments. Three human bladder carcinoma cell lines; HT1376, RT4 and T24, together with the colorectal cell line $\mathrm{Caco} 2$, were obtained from the Collection of Cell Culture (Salisbury, UK). HT1376 cells were maintained in Eagle's modified essential medium (EMEM) (Sigma-Aldrich, Dorset, UK); RT4 and T24 in McCoy's 5A medium (Sigma-Aldrich); and Caco2 in RPMI-medium (Sigma-Aldrich) at $37^{\circ} \mathrm{C}$ in a $5 \%$ carbon dioxide atmosphere. 
Media were supplemented with $10 \%$ FCS, 4 mM L-glutamine, $0.06 \mathrm{mg} / \mathrm{ml}$ benzylpenicillin and $0.1 \mathrm{mg} / \mathrm{ml}$ streptomycin.

In separate experiments, cells were incubated with i) $100 \mathrm{ng} / \mathrm{ml}$ Fas-L (Calbiochem, Nottingham, UK) for $16 \mathrm{~h}$, ii) MMC $(0-500 \mu \mathrm{g} / \mathrm{ml})$ for $1 \mathrm{~h}$ or iii) with either 1 or $12 \mu \mathrm{M} 5$-aza2'-deoxycytidine (5azadC) (Sigma-Aldrich) for $72 \mathrm{~h}$ to assess functionality of the Fas pathway, MMC chemosensitivity and the effects of global methylation, respectively.

Immunocytochemistry on cell lines. Immunocytochemistry on treated and untreated cell lines prior to and after treatments was performed as described. Unfixed (Fas), methanol fixed (p53) or cells fixed in Carnoy's and acid denatured with $1 \mathrm{M}$ $\mathrm{HCl}$ at $60^{\circ} \mathrm{C}$ for $10 \mathrm{~min}(5 \mathrm{MeC})$, were incubated for $1 \mathrm{~h}$ at RT with $5.0 \mu \mathrm{g} / \mathrm{ml}$ anti-Fas (DX2), $8.0 \mu \mathrm{g} / \mathrm{ml}$ anti-p53 (DO7) or $2 \mu \mathrm{g} / \mathrm{ml}$ anti-5-methylcytidine (anti-5MeC) antibodies, respectively. IgG1 or IgG2b antibodies were used at equivalent concentrations as controls. Antibody binding was visualized using EnVision, fluorescein isothiocyanate isomer 1 (FITC) secondary antibody or RPE (Dako) prior to analysis on a Coulter Epics Elite ESP flow cytometer as described for the harvested tumor cells. Data were stored as listmode files and subsequently analysed using Immuno-4 software (Beckman Coulter) which generated the percentage of positively staining cells (\%) and the intensity of immunofluorescence (MCF).

Western blotting on cell lines. Fas and p53 were extracted from cells grown in culture using the ProteoExtract ${ }^{\circledR}$ Native Membrane Protein Extraction kit (Calbiochem) and the NE-PER ${ }^{\circledR}$ Nuclear and Cytoplasmic Extraction Reagents (Pierce Biotechnology), respectively, according to manufacturer's instructions. Ten micrograms of membrane or nuclear protein were denatured, reduced and resolved on 4-12\% gels (Invitrogen) by SDS-PAGE before transfer onto $0.2-\mu \mathrm{m}$ pore size nitrocellulose membrane (Invitrogen). Membranes treated with blocking buffer (3\% BSA in TBST) for $2 \mathrm{~h}$ were probed overnight with either rabbit antihuman Fas polyclonal antibody (antiserum C20) from Santa Cruz Biotechnology Inc., Heidelberg, Germany diluted 1:200 or $2.0 \mu \mathrm{g} / \mathrm{ml}$ anti-p53 (Dako).

Flow cytometry assessment of cell cycle and sub G0/G1 events in cell lines. For assessment of apoptosis, alcohol-fixed cells, both treated and untreated, were washed in PBS before staining with propidium iodide. At least 10,000 events, gated using peak versus integral fluorescence to eliminate doublets and clumps, were collected through a $610-\mathrm{nm}$ long pass filter. DNA histograms were evaluated and events falling within a sub-G0/G1 gate were enumerated.

p53 siRNA transfection in RT4 cells. RT4 cells were incubated with $100 \mathrm{nM}$ p53 siRNA (Dharmacon, UK), control siRNA (Dharmacon) or transfectant only according to manufacturer's instructions. Untransfected cells were included as additional controls. Cells were cultured in fresh growth medium for a further $24 \mathrm{~h}$ before treatment with $50 \mu \mathrm{g} / \mathrm{ml} \mathrm{MMC} \mathrm{or} \mathrm{control}$ media for $1 \mathrm{~h}$. To inhibit p53 induction following MMC treatment, cells were re-transfected with p53 siRNA or control siRNA and cultured for a further $24 \mathrm{~h}$. Levels of p53 and Fas and the number of sub G0/G1 events were assessed using flow cytometry, as described.
FADD-DN transfection to inhibit the Fas apoptotic pathway in RT4 cells. RT4 cells were transfected with a FADD-DN construct [cDNA corresponding to amino acids 80-208 of FADD together with an N-term AU1 epitope tag (22) or empty vector by electroporation using a Nucleofector ${ }^{\circledR}$ Device (Amaxa Biosystems, Cologne, Germany)]. Transfected cells were selected using $500 \mu \mathrm{g} / \mathrm{ml} \mathrm{G} 418$ (BD Biosciences, Oxford, UK) over 3 months. Stable integration and expression of the AU1-tagged FADD-DN was confirmed by immunocytochemical detection using $5 \mu \mathrm{g} / \mathrm{ml}$ of anti-AU1 antibody (Abcam). DN-FADD and vector transfected cells growing on coverslips were treated for $1 \mathrm{~h}$ with $10 \mu \mathrm{g} / \mathrm{ml} \mathrm{MMC} \mathrm{or} \mathrm{control} \mathrm{media} \mathrm{followed} \mathrm{by} \mathrm{incuba-}$ tion in MMC-free media for $24 \mathrm{~h}$. An observer, blinded to the treatments, determined the number of apoptotic cells in 20 high power fields (HPF) on Giemsa stained preparations.

Bisulfite genomic sequencing of the Fas promoter region in cell lines. We determined the effects of 5azadC treatment on Fas immunoreactivity in HT1376, RT4 and T24 cells prior to Bisulfite Genomic Sequencing (BGS). We bisulfite treated extracted DNA from the three cell lines prior to using published primers (19) (Table I) to amplify a 583-bp region of the Fas promoter $(-575$ to +8$)$ which contains $28 \mathrm{CpG}$ dinucleotides.

The amplified Fas promoter fragment was ligated into the pcR2.1TOPO vector and transformed into TOP10 competent E. coli using the TOPO TA Cloning kit (Invitrogen). Multiple clones were analyzed using EcoRl restriction endonuclease digestion (RE) and agarose gel electrophoresis to confirm insertion of the Fas promoter fragment. Two independent positive PCR and RE clones from each sample were subjected to direct sequencing using the BigDye ${ }^{\circledR}$ Terminator v1.1 Cycle Sequencing kit (ABI) and the ABI PRISM ${ }^{\text {TM }} 310$ Genetic Analyser according to manufacturer's instruction. Data were analysed using SeqMan II software (DNAStar) to produce a consensus sequence from each clone.

Methylation-specific PCR on tumor samples and cell lines. Methylation specific PCR (MSPCR) was carried out on extracted tumor DNA from the TCCB patients recruited to Study 2. Total genomic DNA was successfully extracted from $5-\mu \mathrm{m}$ sections from representative tumor blocks from 38 patients and three cell lines using the Ex-Wax DNA Extraction kit (Intergen) or the DNeasy ${ }^{\mathrm{TM}}$ Tissue kit (Qiagen), respectively, according to manufacturer's instructions. MSPCR primers were used to determine the methylation status of i) the potential methylation hotspot at $\mathrm{CpG}$ site -548 within the Fas promoter in 24 patients, ii) the p53 enhancer region within the first intron of the Fas gene (19) in 38 patients and iii) the Sp1 binding region within the Fas promoter in 38 patients (Table I). Prior to MSPCR, $1 \mu \mathrm{g}$ of DNA was bisulfite-treated using the bisulfite CpGenome ${ }^{\mathrm{TM}}$ DNA Modification kit (Chemicon) according to manufacturer's instructions. Bisulfite modified Caco2 DNA, which is heavily methylated in both the promoter and p53 enhancer regions of Fas, was used as a positive methylation control. Previously published PCR amplification conditions were used (19), with differing annealing temperatures of 69,64 and $60^{\circ} \mathrm{C}$ for the target regions $\mathrm{CpG}-548$, p53 enhancer and Sp1 binding site, respectively. MSPCR products were visualised by electrophoresis on $2 \%$ ethidium bromide stained agarose gels. 
Table I. Summary of the PCR primers used for mutational analysis, MSPCR and bisulphite genomic sequencing.

\begin{tabular}{|c|c|c|c|c|}
\hline Analysis & $\begin{array}{l}\text { Target } \\
\text { region }\end{array}$ & $\begin{array}{l}\text { Primer } \\
\text { name }\end{array}$ & 5' Sequence 3' & $\begin{array}{l}\text { PCR product } \\
\text { (bp) }\end{array}$ \\
\hline \multirow[t]{2}{*}{ MSPCR } & $-548 \mathrm{CpG}$ & $\mathrm{MF} 1 \mathrm{C}$ & GGTTTTTGTATTTAGGTAGGATTTTTGC & \\
\hline & site & MR1C & ССААССТССТАСССТТТСТАААААС & 113 \\
\hline \multirow[t]{2}{*}{ MSPCR } & $-548 \mathrm{CpG}$ & UF1C & GGTTTTTGTATTTAGGTAGGATTTTTGT & \\
\hline & site & UR1C & ССААССТССТАСССТТТСТАААААС & 113 \\
\hline \multirow[t]{2}{*}{ MSPCR } & p53 & MF53 & AGTTTCGGCGTTTTTCGGAGATTATTGC & \\
\hline & enhancer & MR53 & CACCCGCGCCGAAACGAACC & 184 \\
\hline \multirow[t]{2}{*}{ MSPCR } & p53 & UF53 & GGTAGTTTTGGTGTTTTTTGGAGATTATTGT & \\
\hline & enhancer & UR53 & САСССАСАССАAАACAАACСТТТААС & 187 \\
\hline \multirow[t]{2}{*}{ MSPCR } & Sp1 & MFsp & GAGTTCGTTTTTGATTTCGC & \\
\hline & region & MRsp & AATATATTCCGTACCAATACCCG & 131 \\
\hline \multirow[t]{2}{*}{ MSPCR } & Sp1 & UFsp & TGAGTTTGTTTTTGATTTTGTGT & \\
\hline & region & URsp & ATATATTCCATACCAATACCCACC & 132 \\
\hline \multirow[t]{2}{*}{ BGS } & Fas & $\mathrm{PF}$ & GGTTTTTGTATTTAGGTAGGATTTTTG & \\
\hline & promoter & PR & СССАACATAАТТАТТАААСААТССТС & 583 \\
\hline \multirow[t]{2}{*}{ Mutation } & Exon 9 & $\mathrm{AF}$ & TGCTGGAGTCATGACACTAAGT & \\
\hline & & $\mathrm{AR}$ & CAATGTGTCATACGCTTCTTTC & 175 \\
\hline \multirow[t]{2}{*}{ Mutation } & Exon 9 & $\mathrm{BF}$ & TAATTGGCATCAACTTCAT & \\
\hline & & $\mathrm{BR}$ & GAATTTGTTGTTTTTCACTCTA & 191 \\
\hline \multirow{2}{*}{ Mutation } & Exon 9 & $\mathrm{CF}$ & TGCTGGAGTCATGACACTAAGT & \\
\hline & & $\mathrm{CR}$ & CAATGTGTCATACGCTTCTTTC & 156 \\
\hline
\end{tabular}

PCR amplification and exon 9 sequencing of DNA extracted from 38 TCCB patients. Mutations within exon 9 which encodes the death domain of Fas have been linked with bladder cancer (20). We examined three specific mutations in this region using previously described primers (20) and direct DNA sequence analysis in DNA extracted from 38 patients. Each of the exon 9 PCR products were gel purified electrophoresed on a $2 \%$ ethidium bromide stained agarose gel to detect product which was purified using Wizard ${ }^{\circledR}$ PCR Preps DNA purification system (Promega) and subjected to direct DNA sequence analysis according to manufacturer's instructions. Data were analysed using SeqMan II software (DNAStar) to produce a consensus sequence for each amplified exon 9 product.

Statistics. Statistical comparisons were performed using SPSS for Windows Version 17. Pearson's $\chi^{2}$ and t-test were used to identify significant associations and differences, respectively. The significance level was $\mathrm{p}<0.05$.

\section{Results}

Intravesical MMC treatment increased Fas and p53 expression in vivo in tumor cells from some patients. Bladder washings from 31 TCCB patients were analysed to determine whether p53 and/or Fas protein expression was up-regulated in response to MMC (Fig. 1). Cytological assessment confirmed that bladder washings contained normal urothelial and tumor cells; some of which were undergoing apoptosis (Fig. 2A). Dynamic p53 up-regulation in tumor cells after intravesical
MMC was assessed in 10 pTa, three pT1 and one unresectable tumor from 13 males and one female (mean age 67.5 years) (mean follow-up, 5 months). One patient withdrew from the study. Nine of the 14 (64\%) patients shed tumor cells which dynamically up-regulated p53 following MMC treatment. There was no evidence of p53 up-regulation in cells obtained from the patient with an unresectable tumor who later died from a lung metastasis. Dynamic Fas up-regulation in tumor cells was assessed in two pTaG1, six pTaG2, one pTaG3, six pT1G3 and one pT2G3 from 15 males and one female (mean age, 67.0 years) (mean follow-up, 13.5 months). The first four patients were used to establish the Fas immunostaining. Unfortunately, control samples in three patients failed. Seven of the nine remaining patients up-regulated Fas following intravesical MMC; two were recurrence-free, four had recurrences and one had $\mathrm{pTaG} 2$ disease (there was no follow-up for this patient). One patient who progressed and one with pT2G3 disease had static Fas immunoreactivity (Fig. 2B).

Positive Fas immunoreactivity (IHC) is associated with advanced disease. One tumor was a squamous cell carcinoma and was excluded from the study. Twenty-five pTa, 16 pT1, seven pT 2 and one pT 3 tumor were collected from 45 males and three females (mean follow-up,14.2 months). Fas IHC failed in one tumor and p53 IHC in two. Fas immunoreactivity detected in 31/47 (67\%) tumors assessed, was significantly associated with progression $\left(\mathrm{p}=0.014 ; \chi^{2}\right.$ test). Nuclear $\mathrm{p} 53$ IHC positivity was observed in $24 / 48(50 \%)$ tumors and was significantly associated with progression, grade and stage $(\mathrm{p}=0.046,0.014$ and 0.021 , respectively; $\chi^{2}$ test) (Fig. 2C). 
A

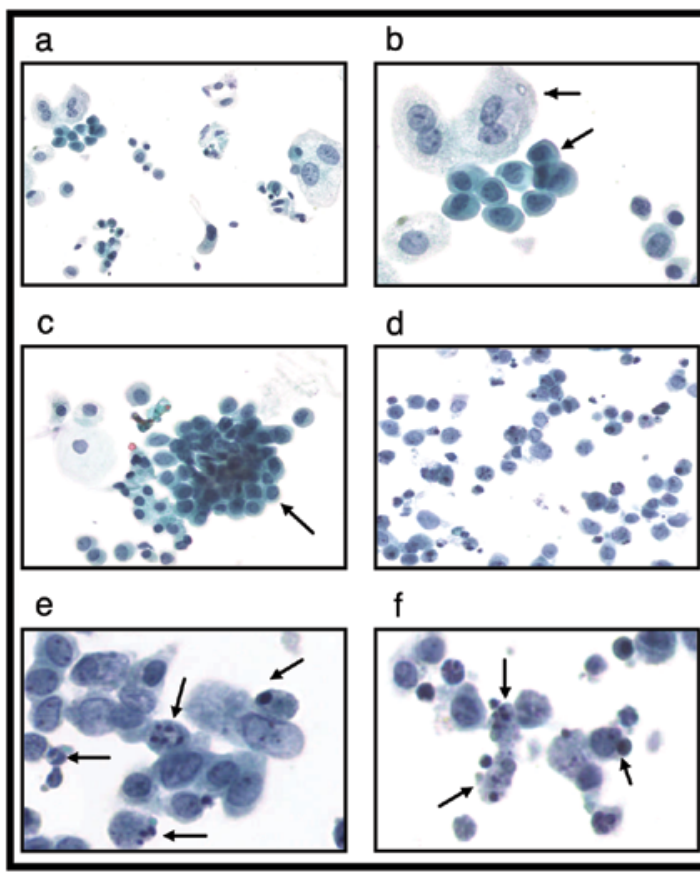

B

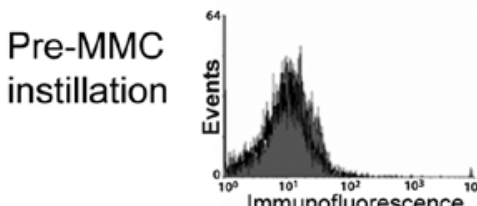

$6 \mathrm{~h}$ post MMC
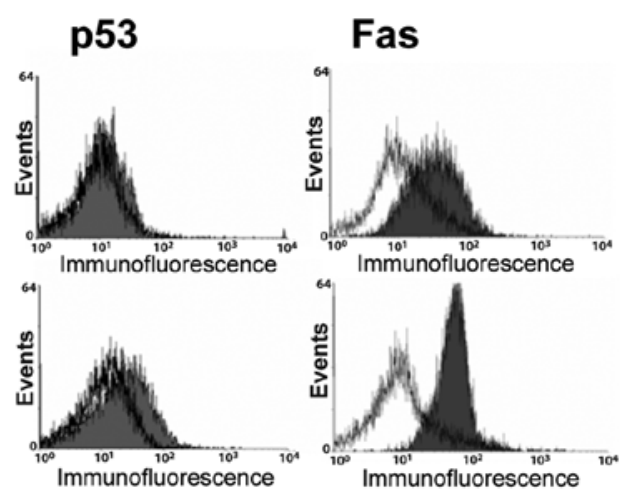

\section{Fas}

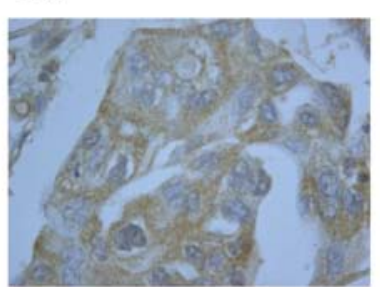

Frank p53

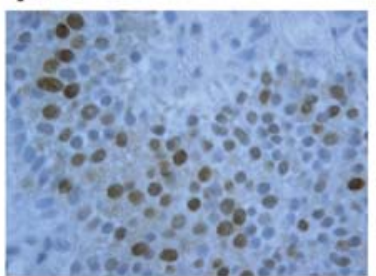

Invasive

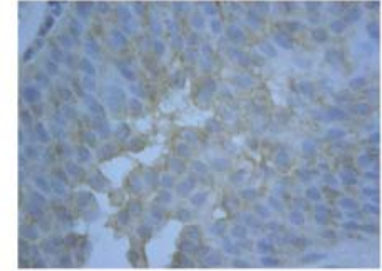

Membranous

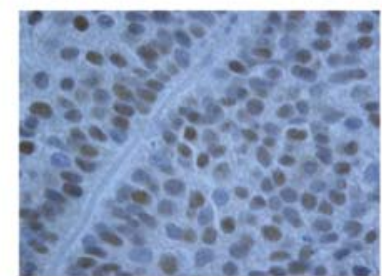

Grade 2

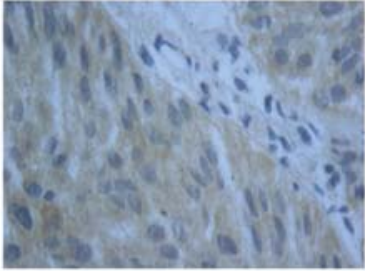

Cytoplasmic

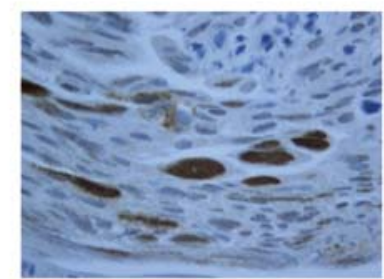

Grade 3

Figure 2. Intravesical MMC treatment increased Fas and p53 expression in vivo in tumor cells. (A) There was no evidence of apoptosis in the cytospin preparations from pretreatment bladder washings. The cell population was mixed and contained normal and urothelial cells (arrowed) (a-c). Cytospin preparations post-MMC demonstrated an abundance of apoptosis. Characteristic features of apoptosis included clumping of chromatin, nuclear fragmentation and membrane blebbing (arrowed) (d-f). (B) In vivo Fas up-regulation in the first $24 \mathrm{~h}$ following MMC was detected in $7 / 9$ patients recruited to the Fas study and p53 up-regulation in 9/14 patients. Cells retrieved from bladder washings were directly immunostained for Fas using $1.5 \mu \mathrm{g} / \mathrm{ml}$ (DX2-RPE) or were sequentially incubated with p53 or IgG2b isotype control antibodies, followed by red phycoerythrin labeled secondary antibody prior to analysis using quantitative flow cytometry. Representative overlay histograms show up-regulation of Fas and p53 following MMC treatment. The isotype control histogram (not filled) was subtracted from its corresponding test histogram (filled) to determine the intensity of immunofluorescence (MCF) at multiple time-points within the first $24 \mathrm{~h}$ following treatment. (C) Positive Fas immunoreactivity in 32/48 tumor samples was observed in three different patterns; frank, membranous and cytoplasmic. Nuclear p53 immunoreactivity associated with higher grade disease, was observed in 17/25 (63\%) of grade 3 tumors, $7 / 19$ (41\%) grade 2 tumors and was absent from the four grade 1 tumors. p53 immunoreactivity was frequently evident in areas of invasion.

Fas immunoreactivity is most intense in T24 cells, but RT4 cells were the only cells to respond to Fas ligand and are most sensitive to $M M C$. Fas immunoreactivity was more intense and cytoplasmic (data not shown) in T24 cells $(\mathrm{MCF}=26.2)$ than in RT4 cells $(\mathrm{MCF}=7.6)$. T24 cells have mutated p53 and have been described as 'mesenchymal' cells with epithelial mesenchymal transition characteristics; RT4 cells have wt p53, are epithelial and less aggressive $(23,24)$. Fas immunoreactivity was absent in HT1376 cells. The extra band detected by Western blotting in RT4 cells may represent a post-translational modification, such as glycosylation at the extracellular domain of the protein $(25,26)$. RT4 cells were 


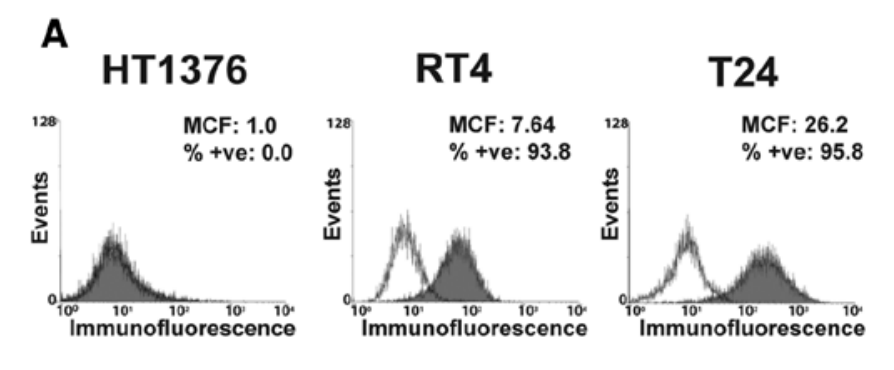

B

HT1376 T24 RT4

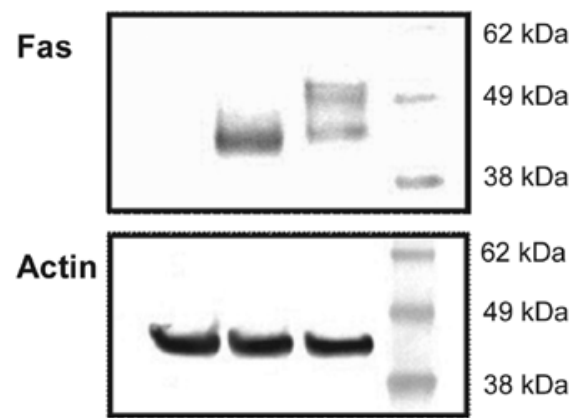

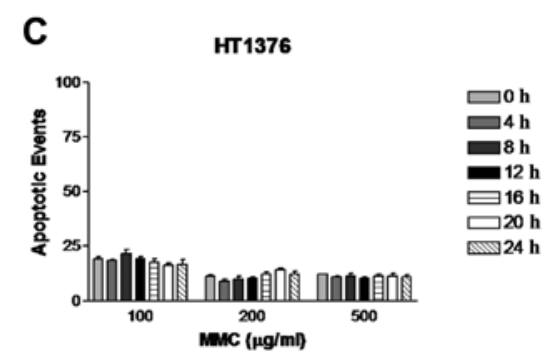

RT4
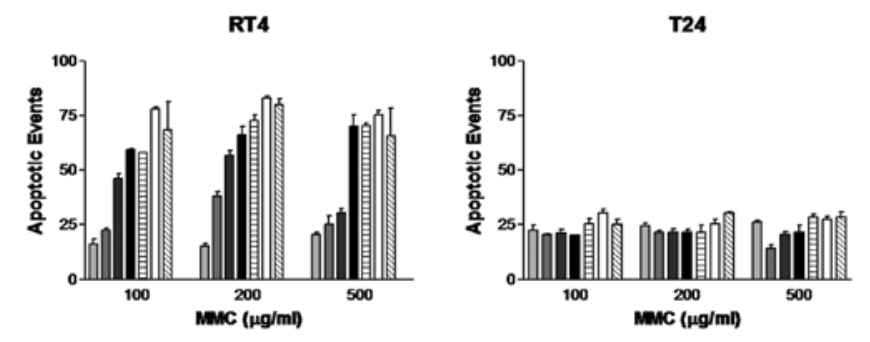

E

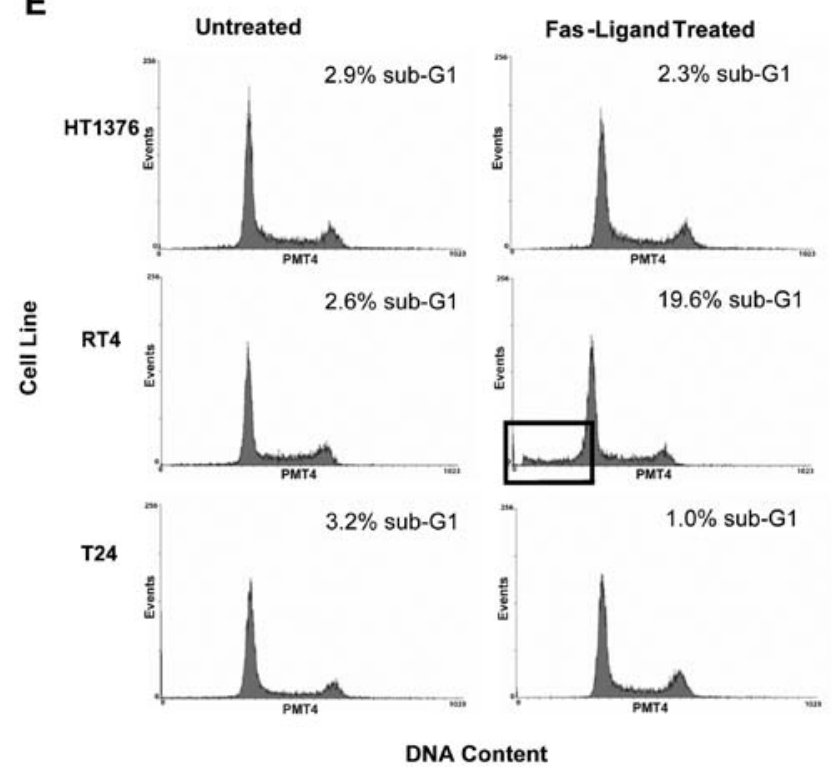

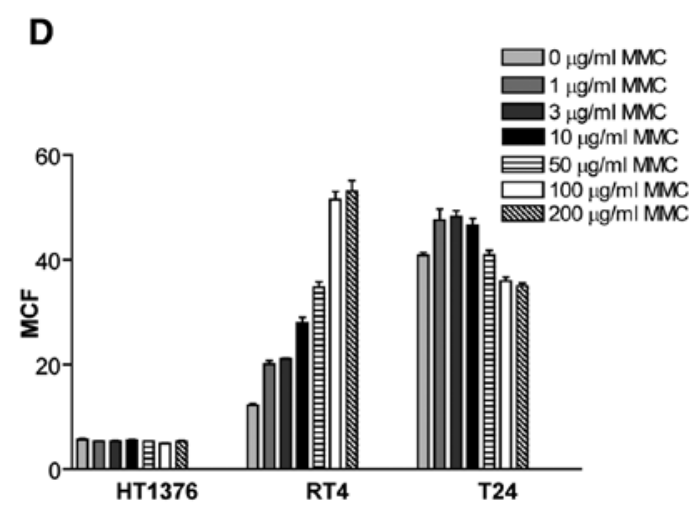

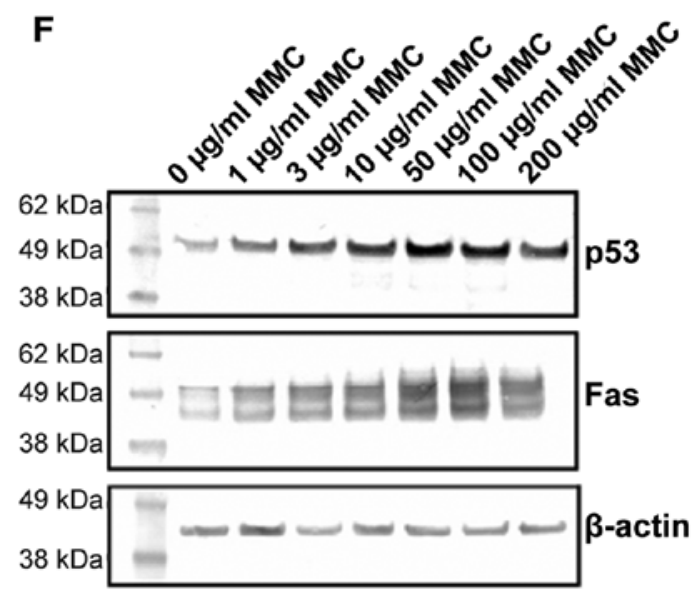

Figure 3. RT4 cells are most MMC sensitive when compared to T24 and HT1376 bladder cancer cell lines. (A) Untreated cells were sequentially incubated with Fas, p53, IgG1 or IgG2b isotype antibodies, followed by red phycoerythrin labeled secondary antibody prior to analysis using quantitative flow cytometry. The isotype control histogram (not filled) was subtracted from the test histogram (filled) to determine the percentage of positively staining cells (\% +ve) and the mean channel fluorescence (MCF). T24 cells exhibited intense Fas immunoreactivity in $>95 \%$ of cells. (B) Membrane proteins (10 $\mu \mathrm{g})$ extracted from HT1376, T24 and RT4 cell lines and probed for Fas again showed that Fas protein expression was greatest in T24 cells. (C) HT1376, RT4 and T24 cells were treated with 100,200 or $500 \mu \mathrm{g} / \mathrm{ml} \mathrm{MMC} \mathrm{for} 1 \mathrm{~h}$ to mimic the clinical scenario and were then assessed for apoptosis after $24 \mathrm{~h}$. The number of sub G0/G1 events was detected after propidium iodide staining. RT4 cells exhibited a classical dose response. T24 and HT1376 cells were resistant. (D) HT1376, T24 and RT4 cells were untreated or treated with between 1 and $200 \mu \mathrm{g} / \mathrm{ml} \mathrm{MMC}$. Fas protein expression was assessed using flow cytometry $24 \mathrm{~h}$ later. There was a classical dose response induction of Fas in RT4 cells. (E) Significant apoptosis was induced in RT4 cells following treatment with $100 \mathrm{ng} / \mathrm{ml}$ soluble recombinant human Fas-L for $16 \mathrm{~h}$. (F) RT4 cells were treated with between 1 and $200 \mu \mathrm{g} / \mathrm{ml}$ MMC and harvested after $12 \mathrm{~h}$ for Western blot detection of nuclear p53 and after $24 \mathrm{~h}$ for detection of membranous Fas. After $12 \mathrm{~h}$ the band intensity for p53 increased as the MMC concentration increased and similarly, for Fas the band intensity increased after $24 \mathrm{~h}$ suggesting that Fas up-regulation might be p53-dependent. 
A

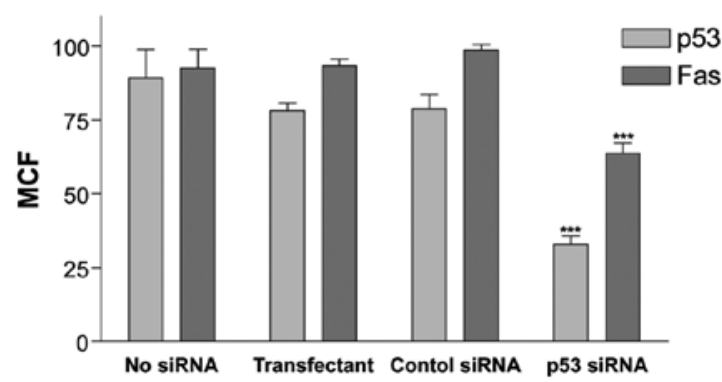

B

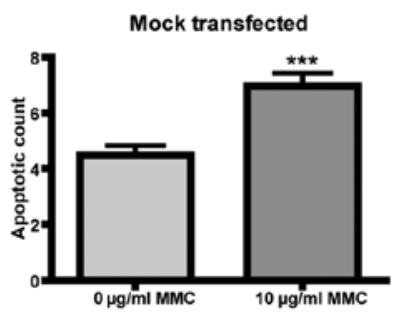

DN-FADD Transfected

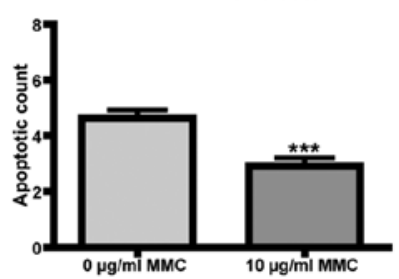

Figure 4. MMC apoptotic response in RT4 cells is p53- and Fas-dependent. (A) RT4 cells were incubated in media, media supplemented with the transfection reagent only, supplemented with control siRNA or supplemented with p53 siRNA. All cells were then treated in media supplemented with $50 \mu \mathrm{g} / \mathrm{ml} \mathrm{MMC}$. MMC-induced up-regulation of Fas in RT4 cells was significantly decreased following p53 siRNA (p<0.001). (B) RT4 cells transfected with FADD-DN had significantly fewer apoptotic cells/HPF than mock transfected cells $24 \mathrm{~h}$ after treatment with $10 \mu \mathrm{g} / \mathrm{ml} \mathrm{MMC}(\mathrm{p}<0.001)$.

the most sensitive to MMC. Membranous Fas expression significantly increased in RT4 cells $(\mathrm{p}=0.002)$, but not in T24 $(\mathrm{p}=0.078)$ or HT1376 cells $(\mathrm{p}=0.229) 24 \mathrm{~h}$ after treatment with $1 \mu \mathrm{g} / \mathrm{ml} \mathrm{MMC.} \mathrm{RT4} \mathrm{were} \mathrm{the} \mathrm{only} \mathrm{cells} \mathrm{responsive} \mathrm{to}$ Fas Ligand, suggesting that RT4 cells had functional Fas (Fig. 3).

MMC response in RT4 cells is p53-and Fas-dependent. Having established that levels of p53 increased prior to increases in Fas levels we wished to gain greater insight into the dynamics of p53 and Fas up-regulation in response to MMC using RT4 cells as a model. RT4 cells were originally derived from a grade 1 tumor expressing $w t \mathrm{p} 53$. To determine if Fas up-regulation was dependent on p53, RT4 cells were transfected with p53 siRNA before and after treatment. MMC-induced up-regulation of p53 and Fas in RT4 cells was significantly decreased following p53 siRNA ( $<<0.001)$. Furthermore, $24 \mathrm{~h}$ after treatment with $10 \mu \mathrm{g} / \mathrm{ml}$ MMC apoptosis was significantly less in RT4 cells transfected with FADD-DN than in mock transfected cells $(\mathrm{p}<0.001)$ (Fig. 4).

Demethylation with 5-aza-2'deoxycytidine induced Fas immunoreactivity in HT1376 cells. Having demonstrated that Fas plays an important role in the apoptotic response to MMC chemotherapy in RT4 cells, we investigated methylation as a possible mechanism of the Fas silencing observed in HT1376 cells. Treatment with $1 \mu \mathrm{M}$ 5azadC for $72 \mathrm{~h}$, significantly increased Fas immunoreactivity in RT4 cells, but did not change immunoreactivity in T24 cells or induce Fas immunoreactivity in HT1376 cells. However, $72 \mathrm{~h}$ after treatment with $12 \mu \mathrm{M} 5 \mathrm{azadC}$, Fas immunoreactivity increased in a subpopulation of HT1376 cells and anti-5MeC immunoreactivity was significantly reduced $(\mathrm{p}=0.010)$ (Fig. 5A-C).

Methylation at a single CpG site in the Fas promoter: a novel methylation hotspot. We investigated the methylation of specific $\mathrm{CpG}$ in the promoter of Fas gene. Altered methylation may be responsible for the Fas immunoreactivity observed in HT1376 cells and the increased expression observed in RT4 after 5azadC treatment. We assessed the $28 \mathrm{CpG}$ sites located within the Fas promoter $(-575$ to +8$)$ using Bisulfite Genomic Sequencing (Table I). The Fas promoter region in HT1376, but not RT4 or T24 was methylated at a single CpG site (-548).
Methylation at this $\mathrm{CpG}(-548)$ in HT1376 was reversed following treatment with $12 \mu \mathrm{M} 5 \mathrm{azadC}$ for $72 \mathrm{~h}$ (Fig. 5D).

Using MSPCR primers for CpG -548 in the Fas promoter (Table I) we detected methylated bands in 13/24 (54\%) tumors assessed. Unexpectedly, eight of these tumors (62\%) exhibited Fas immunoreactivity. Interestingly, this immunoreactivity was predominantly cytoplasmic. Possibly cytoplasmic Fas is non-functional. There was no association between methylation at $\mathrm{CpG}-548$ and grade, stage or age. Patients with methylation had a mean age of 68.5 years compared to 66.3 years in those with unmethylated tumors. This was not statistically significant. When we assessed DNA extracted from 38 tumors, including six pT2 lesions, we found no evidence of methylation either within the p53 enhancer region of intron 1 or in the area adjacent to an SP-1 transcription factor binding site (Fig. 5E). Similarly, we found no evidence of mutations in exon 9 of Fas as previously reported by Lee et al (20) (Fig. 6).

\section{Discussion}

A single CpG (-548) in the promoter of Fas was methylated in $13 / 24(54 \%)$ bladder tumors that we investigated. This finding is important because we also report that demethylation of HT1376 cells induce Fas immunoreactivity. In addition, we highlight how functional Fas protein plays a key role in MMC-induced apoptosis and hence that its silencing may be associated with MMC resistance. We caution that Fas immunoreactivity is not, in itself, indicative of a good prognosis because in certain instances, similar to p53, it is not functional Fas. We are the first to report, in vivo, dynamic up-regulation of pro-apoptotic proteins, as detected by flow cytometry in tumor cells, and its associated with a favorable prognosis. These data together suggest that the ability of a tumor cell population to increase expression of pro-apoptotic proteins after MMC chemotherapy may predict response to MMC.

Because 16/48 bladder tumors did not express Fas, we investigated the mechanisms involved in Fas silencing. We identified a novel methylation hotspot at $\mathrm{CpG}$ site -548 within the Fas promoter and document, for the first time, an up-regulation and re-expression of membranous Fas in bladder cancer cells post-global demethylation in HT1376 cells. We monitored p53 protein expression post-5azadC treatment and found no evidence of increased p53 expression. This 
A

- 5-azadC

+ 5-azadC
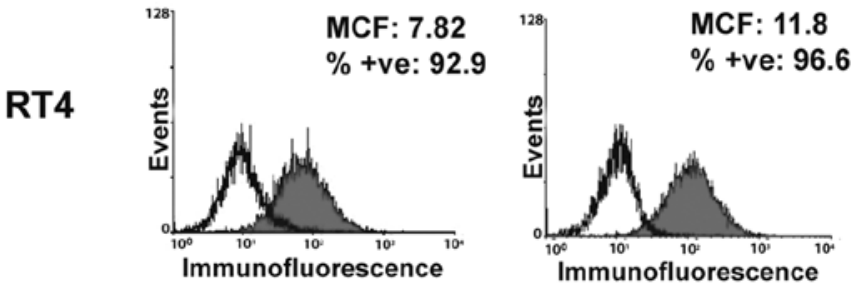

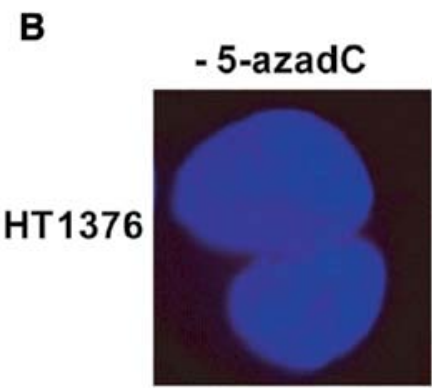

Fas negative

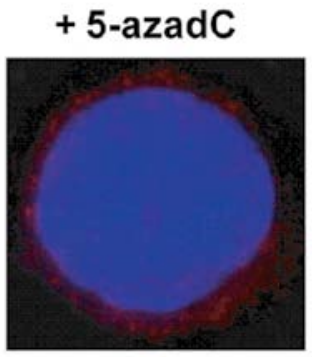

Fas positive

D
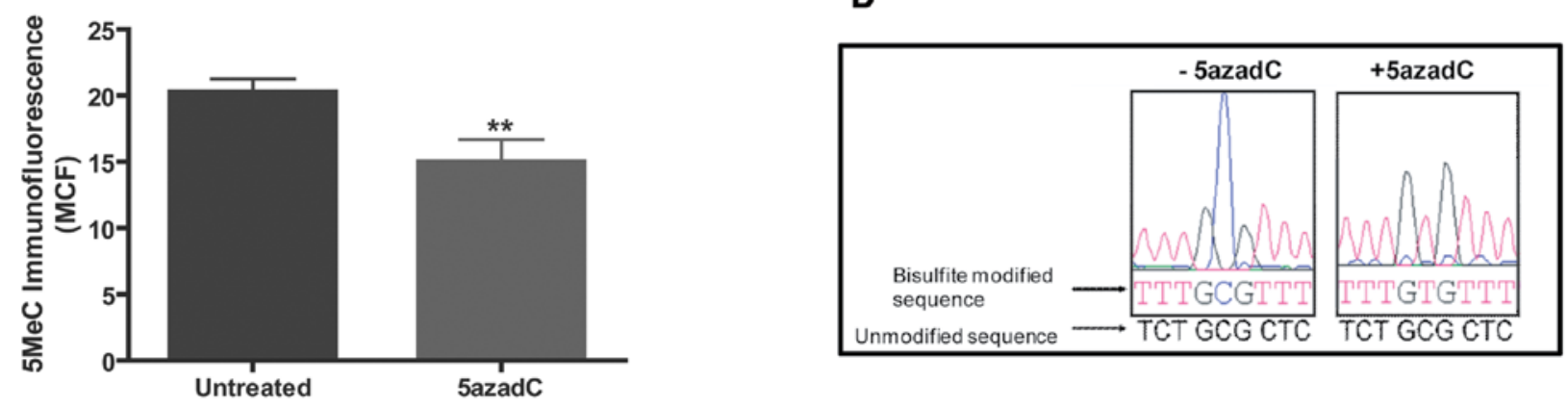

E

I

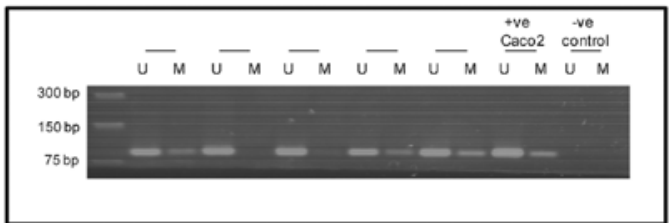

II

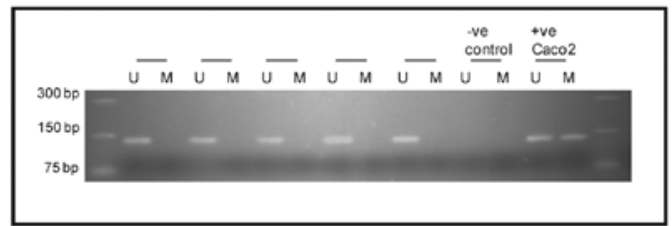

III

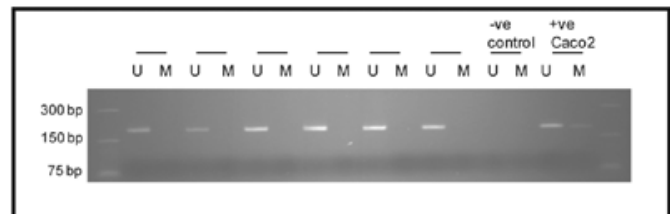

Figure 5. Global demethylation of HT1376 cells with 5azadC removed methyation from one CpG site in the FAS promoter and induced Fas expression. (A) Global demethylation with $5 \mathrm{azadC}$ at concentrations of 1 and $12 \mu \mathrm{M}$, respectively, for $72 \mathrm{~h}$ increased Fas protein expression in RT4 and HT1376 cells. Untreated and 5azadC-treated RT4 and HT1376 cells were immunostained for Fas using DX2 (Dako) and 5-methylcytidine (5MeC) using 5MeC monoclonal antibody from Eurogentec, Ltd., Southampton, UK and then analysed using quantitative flow cytometry. (B) Membranous Fas expression was observed in HT1376 cells which had been demethylated with $12 \mu \mathrm{M} 5 \mathrm{azadC}$ for $72 \mathrm{~h}$ and then immunostained for membranous Fas expression and counterstained with DAPI. (C) 5MeC immunoreactivity significantly decreased ( $\mathrm{p}<0.001$ ) in HT1376 cells following treatment with $12 \mu \mathrm{M}$ 5azadC for $72 \mathrm{~h}$. (D) Bisulfite genomic sequencing of the HT1376 Fas promoter revealed methylation at one CpG site (-548) which was removed following global demethylation using $12 \mu \mathrm{M} 5 \mathrm{azadC}$ for $72 \mathrm{~h}$. (E) DNA extracted from paraffin blocks of tumor-rich samples was bisulfite treated before MSPCR. Representative gels demonstrate that we found (I) methylation at a CpG site (-548) of the Fas promoter in 13/24 bladder tumors assessed (II) no evidence of methylation in tumor samples from 38 TCCB patients, including six with pT2 disease, at the site within the p53 enhancer region and similarly (III) no evidence of methylation in the 38 tumors assessed at the SP-1 binding site which again included six patients with muscle invasive disease. In all gels the $\mathrm{Caco} 2$ positive control had both methylated and unmethylated bands and the control DNA had no bands.

confirms that increased Fas immunoreactivity was attributable to demethylation and not downstream effects of a p53 damage response to the demethylating agent (data not shown). The single CpG site which was hypermethylated in HT1376 cells has previously been reported in two colorectal cell lines (19). Our findings in HT1376 would suggest that there is a potential 
A

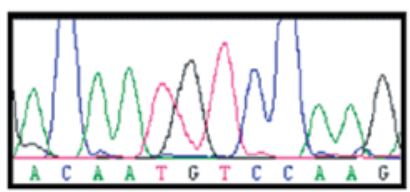

B

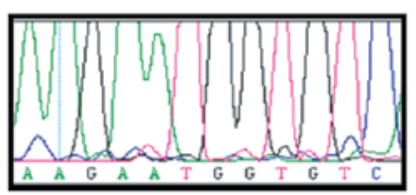

Figure 6. No evidence of in exon 9 of Fas in tumor samples DNA was extracted from representative paraffin tumor samples from 38 TCCB patients, including six with pT2 disease. DNA was successfully amplified using the three sets of primers previously described (20) (Table I). Representative sequence electrographs from TCCB patients with (A) pT2aG3 and (B) pT1G3 tumors at the previously described $\mathrm{G} \rightarrow \mathrm{A}$ transition at bp 993 and $\mathrm{T} \rightarrow \mathrm{G}$ transition at bp 950 sites indicated by the red arrows (20). Close analyses of electrograms revealed no evidence of gene mutation using any of the three regions in any of the 38 TCCB samples analysed.

methylation hotspot within Fas that may impact on its gene expression.

The single $\mathrm{CpG}$ site (-548) in the promoter was found to be methylated in 13/24 (54\%) bladder tumors investigated. Fas may be one of the tumor suppressor genes released from transcriptional repression following treatment with DNA methylation inhibitors in studies which have reported enhanced susceptibility of bladder (27) and ovarian cancer cells to cisplatin (28). Hypermethylation at this site could potentially decrease therapeutic response rates and may be associated with tumor progression through immune surveillance evasion. Only three muscle invasive bladder tumors were screened for methylation at the single $\mathrm{CpG}$ site $(-548)$ in the promoter, two of these were methylated. These numbers preclude meaningful statistical analysis of the association between methylation and tumor stage, but do however, suggest an important trend.

We did not observe any DNA methylation at either the p53 enhancer region or the SP-1 binding region in DNA extracted from the three bladder cancer cell lines or the 38 TCCB samples. Collectively, these observations strongly suggest that aberrant methylation at these two regions is not an important mechanism of Fas dysregulation in bladder cancer.

Our present findings add another level to the understanding of the complexity of the role of deregulated Fas in tumorigenesis which may be enhanced by either silencing of Fas by methylation or by distinct mechanisms which destroy Fas functionality. Eight of the 13 tumors with methylation at $\mathrm{CpG}$ -548 had cytoplasmic Fas immunoreactivity. Five of these eight tumors also had p53 immunoreactivity which is suggestive of p53 mutation. Methylation was found in 5/7 tumors which were negative for p53 immunoreactivity which could suggest that Fas methylation may play a complementary role to p53 in bladder carcinogenesis. Alternatively, it could be that the association between Fas positivity and poor prognosis may be obscured by p53 mutational status. Our finding that T24 cells do not respond to Fas ligand corroborates the report of Perabo et al (29) suggesting that Fas in T24 cells is not functional. Certain patterns of Fas immunoreactivity, including cytoplasmic expression as observed in some tumors in this study, could be a manifestation of non-functional Fas (Fig. 2). Alternatively Fas function may be inhibited by anti-apoptotic proteins including Bcl-2. RT4, T24 and HT1376 all express Bcl-2 immunore- activity. Interestingly, T24 cells are known to be dependent on $\mathrm{Bcl}-2$ for their resistance to MMC $(30,31)$.

Possible mechanisms leading to aberrant Fas hypermethylation in bladder cancer could be attributed to epigenetic dysregulation in the tumor microenvironment. Such environmental factors include tumor hypoxia $(32,33)$, DNA damage (34) and inflammation (35). Dysregulation in the enzymes that regulate DNA methylation may also be involved. The DNA methyltransferase $3 b$ (Dnmt3b), which is responsible for generating de novo methylation during development, is dramatically overexpressed in several tumor cell lines and tumor specimens, including bladder (36,37). Kimura et al assessed 45 bladder tumors, 40 of which were high stage/grade, and reported that Dnmt3b mRNA levels were overexpressed in approximately half of the tumors examined, in comparison to levels in morphologically normal bladder tissues (38). One direct mechanism that results in Fas hypermethylation involves oncogenic Ras. Activating Ras mutations are extremely common in bladder tumors. Interestingly, T24 cells harbor the single point mutation at codon 12 present in $>40 \%$ of bladder tumors (39-41). HT1376 cells have inactive Ras (42). Of significance, Ras has been implicated in the recruitment of DNA methyltransferases to the Fas gene promoter and the subsequent silencing of the Fas gene (43). These findings add to the evidence that the relationship between expression and hypermethylation in the promoter regions of genes in bladder cancer cells is complex as reported in the context of S100A4 (16).

We also investigated exon 9 mutations in the bladder tumors as a potential mechanism of Fas dysregulation. In contrast to Lee et al (20) who demonstrated 11 mutations in 42 patients with bladder cancer, we did not detect any exon 9 Fas mutations by direct sequencing. However, all but one of the patients Lee assessed had muscle invasive disease and 8 of the 11 mutations were an identical $\mathrm{G} \rightarrow \mathrm{A}$ transition at base pair position 993. Korkolopoulou et al (44) and Maas et al (6) who also studied bladder cancer were unable to replicate the findings of Lee et al (20). Explanation for the original finding by Lee et al may reflect the different ethnic population studied.

The impact of our study is that Fas plays a critical role in the response to MMC chemotherapy particularly in patients who present with superficial disease in the absence of p53 mutation, but in the presence of Fas promoter methylation. Unlike genetic alterations, epigenetic aberrations are reversible and thus provide interesting clinical relevance. Targeting bladder cancer patients harboring methylation at the single $\mathrm{CpG}$ site -548 within the Fas promoter site for treatment with demethylating drugs, such as Vidaza or Dacogen, could be employed as a single drug therapy or as a pre-sensitising strategy prior to MMC chemotherapy.

\section{Acknowledgements}

This study was supported by funding from Department of Employment and Learning Northern Ireland (DEL Research Award -18775993 to C.J.W., K.W. and P.M.); Royal Hospitals Trust [21278 (29632) Patrick Watt Memorial Trust Fund to K.W.]; British Urological Foundation [Edward Scott Memorial Scholarship (2004-2005) to H.O'K.], Belfast City Hospital Charitable Trust Funds (F/021-12/02 to H.O'K.), Peel Medical Research Trust (RRL.R10 to H.O'K.), Royal College of 
Surgeons Edinburgh (to H.O'K.); Research and Development Office Northern Ireland (EAT/1168/99 to J.McK.); Cancer Recognised Research Group Northern Ireland (to K.W. and J.McK.); Private donation in memory of GMJ [to C.J.W.]; Education and Culture Bureau, Egypt (MM172/NI to O.S.) and by grants (KKKII-05/2005, NKFP_07_A2-NANODRUG, TECH_08_A2-STEMKILL, NAP_BIO_06-FLU_DRUG and OTKA-T046665 to I.P.) The authors acknowledge the kind gift of the FADD-DN construct from Vishva Dixit, Molecular Oncology, Genetech, San Francisco, CA, USA.

\section{References}

1. Suda T, Takahashi T, Golstein P and Nagata S: Molecular cloning and expression of the Fas ligand, a novel member of the tumor necrosis factor family. Cell 75: 1169-1178, 1993.

2. Oshimi Y, Oda S, Honda Y, Nagata S and Miyazaki S: Involvement of Fas ligand and Fas-mediated pathway in the cytotoxicity of human natural killer cells. J Immunol 157: 2909-2915, 1996.

3. Peli J, Schroter M, Rudaz C, et al: Oncogenic Ras inhibits Fas ligand-mediated apoptosis by downregulating the expression of Fas. EMBO J 18: 1824-1831, 1999.

4. Owen-Schaub LB: Fas function and tumor progression: use it and lose it. Cancer Cell 2: 95-96, 2002.

5. Mottolese M, Buglioni S, Bracalenti C, et al: Prognostic relevance of altered Fas (CD95)-system in human breast cancer. Int J Cancer 89: 127-132, 2000.

6. Maas S, Warskulat U, Steinhoff C, et al: Decreased Fas expression in advanced-stage bladder cancer is not related to p53 status. Urology 63: 392-397, 2004.

7. Yamana K, Bilim V, Hara N, et al: Prognostic impact of FAS/ CD95/APO-1 in urothelial cancers: decreased expression of Fas is associated with disease progression. Br J Cancer 93: 544-551, 2005.

8. Shimizu M, Yoshimoto T, Sato M, Matsuzawa A and Takeda Y: Frequency and resistance of CD95 (Fas/Apo-1) gene-transfected tumor cells to CD95-mediated apoptosis by the elimination and methylation of integrated DNA. Int J Cancer 119: 585-592, 2006.

9. Herman JG and Baylin SB: Gene silencing in cancer in association with promoter hypermethylation. N Engl J Med 349: 2042-2054, 2003.

10. Rountree MR, Bachman KE, Herman JG and Baylin SB: DNA methylation, chromatin inheritance, and cancer. Oncogene 20 3156-3165, 2001.

11. Wilhelm-Benartzi CS, Koestler DC, Houseman EA, et al: DNA methylation profiles delineate etiologic heterogeneity and clinically important subgroups of bladder cancer. Carcinogenesis 31: 1972-1976, 2010.

12. Jones PA and Baylin SB: The fundamental role of epigenetic events in cancer. Nat Rev Genet 3: 415-428, 2002.

13. Gonzalez-Zulueta M, Bender CM, Yang AS, et al: Methylation of the 5' CpG island of the p16/CDKN2 tumor suppressor gene in normal and transformed human tissues correlates with gene silencing. Cancer Res 55: 4531-4535, 1995.

14. Gonzalgo ML, Hayashida T, Bender CM, et al: The role of DNA methylation in expression of the p19/p16 locus in human bladder cancer cell lines. Cancer Res 58: 1245-1252, 1998.

15. Ribeiro-Filho LA, Franks J, Sasaki M, et al: CpG hypermethylation of promoter region and inactivation of E-cadherin gene in human bladder cancer. Mol Carcinog 34: 187-198, 2002.

16. Dokun OY, Florl AR, Seifert HH, Wolff I and Schulz WA: Relationship of SNCG, S100A4, S100A9 and LCN2 gene expression and DNA methylation in bladder cancer. Int J Cancer 123: 2798-2807, 2008.

17. Brait M, Begum S, Carvalho AL, et al: Aberrant promoter methylation of multiple genes during pathogenesis of bladder cancer. Cancer Epidemiol Biomarkers Prev 17: 2786-2794, 2008.

18. Behrmann I, Walczak H and Krammer PH: Structure of the human APO-1 gene. Eur J Immunol 24: 3057-3062, 1994.

19. Petak I, Danam RP, Tillman DM, et al: Hypermethylation of the gene promoter and enhancer region can regulate Fas expression and sensitivity in colon carcinoma. Cell Death Differ 10: 211-217, 2003.

20. Lee SH, Shin MS, Park WS, et al: Alterations of Fas (APO-1/ CD95) gene in transitional cell carcinomas of urinary bladder. Cancer Res 59: 3068-3072, 1999.
21. Maffezzini M, Simonato A, Zanon M, Raber $M$ and Carmignani G: Up-front intravesical chemotherapy for low stage, low grade recurrent bladder cancer. J Urol 155: 91-93, 1996.

22. Chinnaiyan AM, O'Rourke K, Tewari M and Dixit VM: FADD, a novel death domain-containing protein, interacts with the death domain of Fas and initiates apoptosis. Cell 81: 505-512, 1995.

23. Cooper MJ, Haluschak JJ, Johnson D, et al: p53 mutations in bladder carcinoma cell lines. Oncol Res 6: 569-579, 1994.

24. Sayan AE, Griffiths TR, Pal R, et al: SIP1 protein protects cells from DNA damage-induced apoptosis and has independent prognostic value in bladder cancer. Proc Natl Acad Sci USA 106: 14884-14889, 2009.

25. Itoh N, Yonehara S, Ishii A, et al: The polypeptide encoded by the cDNA for human cell surface antigen Fas can mediate apoptosis. Cell 66: 233-243, 1991.

26. Kamitani T, Nguyen HP and Yeh ET: Activation-induced aggregation and processing of the human Fas antigen. Detection with cytoplasmic domain-specific antibodies. J Biol Chem 272: 22307-22314, 1997.

27. Shang D, Liu Y, Matsui Y, et al: Demethylating agent 5-aza2'-deoxycytidine enhances susceptibility of bladder transitional cell carcinoma to cisplatin. Urology 71: 1220-1225, 2008.

28. Appleton K, Mackay HJ, Judson I, et al: Phase I and pharmacodynamic trial of the DNA methyltransferase inhibitor decitabine and carboplatin in solid tumors. J Clin Oncol 25: 4603-4609, 2007.

29. Perabo FG, Kamp S, Schmidt D, et al: Bladder cancer cells acquire competent mechanisms to escape Fas-mediated apoptosis and immune surveillance in the course of malignant transformation. Br J Cancer 84: 1330-1338, 2001.

30. Cho HJ, Kim JK, Kim KD, et al: Upregulation of Bcl-2 is associated with cisplatin-resistance via inhibition of Bax translocation in human bladder cancer cells. Cancer Lett 237: 56-66, 2006.

31. Duggan BJ, Maxwell P, Kelly JD, et al: The effect of antisense $\mathrm{Bcl}-2$ oligonucleotides on $\mathrm{Bcl}-2$ protein expression and apoptosis in human bladder transitional cell carcinoma. J Urol 166: 1098-1105, 2001.

32. Watson JA, Watson CJ, McCrohan AM, et al: Generation of an epigenetic signature by chronic hypoxia in prostate cells. Hum Mol Genet 18: 3594-3604, 2009.

33. Watson JA, Watson CJ, McCann A and Baugh J: Epigenetics, the epicenter of the hypoxic response. Epigenetics 5: 293-296, 2010.

34. O'Hagan HM, Mohammad HP and Baylin SB: Double strand breaks can initiate gene silencing and SIRT1-dependent onset of DNA methylation in an exogenous promoter CpG island. PLoS Genet 4: e1000155, 2008.

35. Valinluck V and Sowers LC: Inflammation-mediated cytosine damage: a mechanistic link between inflammation and the epigenetic alterations in human cancers. Cancer Res 67: 5583-5586, 2007.

36. Xie S, Wang Z, Okano M, et al: Cloning, expression and chromosome locations of the human DNMT3 gene family. Gene 236: 87-95, 1999.

37. Robertson KD, Uzvolgyi E, Liang G, et al: The human DNA methyltransferases (DNMTs) 1, 3a and 3b: coordinate mRNA expression in normal tissues and overexpression in tumors. Nucleic Acids Res 27: 2291-2298, 1999.

38. Kimura F, Seifert HH, Florl AR, et al: Decrease of DNA methyltransferase 1 expression relative to cell proliferation in transitional cell carcinoma. Int J Cancer 104: 568-578, 2003.

39. Buyru N, Tigli H, Ozcan F and Dalay N: Ras oncogene mutations in urine sediments of patients with bladder cancer. J Biochem Mol Biol 36: 399-402, 2003.

40. Burchill SA, Neal DE and Lunec J: Frequency of H-ras mutations in human bladder cancer detected by direct sequencing. Br J Urol 73: 516-521, 1994.

41. Mo L, Zheng X, Huang HY, et al: Hyperactivation of Ha-ras oncogene, but not Ink4a/Arf deficiency, triggers bladder tumorigenesis. J Clin Invest 117: 314-325, 2007.

42. Makri D, Schulz WA, Grimm M, Clasen S, Bojar H and SchmitzDrager BJ: WAF1/p21 regulates proliferation, but does not mediate p53-dependent apoptosis in urothelial carcinoma cell lines. Int J Oncol 12: 621-628, 1998.

43. Gazin C, Wajapeyee N, Gobeil S, Virbasius CM and Green MR: An elaborate pathway required for Ras-mediated epigenetic silencing. Nature 449: 1073-1077, 2007.

44. Korkolopoulou P, Goudopoulou A, Voutsinas G, et al: c-FLIP expression in bladder urothelial carcinomas: its role in resistance to Fas-mediated apoptosis and clinicopathologic correlations. Urology 63: 1198-1204, 2004. 